\title{
Development and Psychometric Validation of Geography Interest Inventory for Secondary School Students
}

\author{
Erutujiro Goodluck \\ Federal Government Girls College Onitsha, Nigeria \\ DOI - http://doi.org/10.37502/IJSMR.2021.4603
}

\begin{abstract}
In recent time, the number of students' academic performance in geography in secondary schools in Delta State, Nigeria has been on the declined. Therefore, it becomes imperative to know the students interest level in the subject. The study is on development and psychometrics validation of geography interest inventory. The instrument has 27 items. The instrument was administered to a sample of 494 secondary students in Delta State, Nigeria. The sample was randomly split in two halves. The first sample 247 was used for Exploratory Factor Analysis (EFA). The results of the Exploratory Factor Analysis resulted in Four Factor Solution that is emotion, value, Knowledge and engagement. To validate the structure or factors obtained from the EFA, a confirmatory factor analysis was conducted using second sample of 247 . The result of model fit in term of TLI (0.904), CFI (0.917), RMSEA (0.066) and SRMR (0.63) were above the recommended cut of 0.90 for CFI, TLI and less than 0.08 for RMSEA and SRMR respectively. Furthermore, the study also indicates that items loading in the respective dimension were significant. Therefore, the geography interest inventory is valid and reliable.
\end{abstract}

Keywords: Geography, psychometrics, validation, inventory and interest.

\section{Introduction}

Geography is a very wide but interesting subject, which touches on most other subjects such as the social studies or the social environmental studies. It calls for a lot of hard work to master and enjoy it at the S.S.S level but with the right attitude and approach it is usually a pleasure to learn it. Despite this, there has been an observable sharp decline in the number of students that offer geography at the senior secondary level in Nigeria (Akintade, 2011). Also, reports of the students $^{6}$ performance in this aspect of practical geography in Senior Secondary School Certificate Examinations conducted by both West African Examinations Council (WAEC) and National Examinations Council (NECO) have not being encouraging. For instance, WAEC Chief Examiners 'reports have highlighted poor candidates 'performance in SSSCE geography map reading persistently (WAEC, 2015, 2016, 2017, 2018, and 2019). Egunjobi (2014) also noted that quality and poor academic performance of students in geography education is of great 
concern for stakeholders including educators, teachers, parents, students and the Nigerian community at large. According to Estawul, Sababa, Filgona (2016), the underachievement of students in geography in Nigeria over the years has necessitated a series of workshop for geography secondary school teachers organized by the Inspectorate Division of the Ministry of Education.

Okunrotifa (2008) noted that apart from the inadequate academic background of pupils and the limited resources for geography teaching, the quality of teaching offered in our schools is also a major problem. Another major reasons that have been adduced for this is the general lukewarm attitude of students to the study of geography at secondary school level (Olanipekun, 1988) which has been related to the acute shortage of geography teachers thereby impeding the smooth transition of students from social studies in JSS to geography in SSS. Bangbade (2004) concluded that students whose teachers lack the knowledge of the subject matter, who have poor communication ability, poor emotional stability and lack interest in the job do not perform like others whose teachers possess these attributes. Elochukwu (2001) revealed that there was a significant relationship between teaches' ability to communicate effectively and students' academic performance in the secondary schools. Rilwani, Akahomen and Gbakeji (2014) study has shown that acute shortage of geography teachers and poor teaching of the subject are major factors in students' attrition in geography. Others are inadequate teaching facilities and aids as well as the scope of the syllabus. Rena (2000) explained further that for students to perform well in any examination one of the prerequisites is that their teachers must know them and have profound knowledge of their state of physical, intellectual, psychological readiness and interest in the subject.

One of the psychological construct that has attracted the attention of researchers in recent time is interest in geography. Interest according to Guilford (1951) is preference for one activity over another. Interest involves the selection and ranking of activities along a dislike dimension and activities or behavior engaged by individual. According to Obika (2004), interest is individual generalized behavior tendency to be attracted to a certain class of activities. Generally, interest may be seen as one likes and dislikes. It is a psychological trait which could be evaluated through the use of observation, interview and questionnaires. Hidi and Renniger (2006) have identified four dimensions of interest namely emotion, value, knowledge and engagement.

The first widely used interest inventory was the Strong Vocational Interest Blank, developed in 1927 by E.K. Strong. The original test was designed for men only; a version for women was developed in 1933. In 1974 the Strong test was merged into the Strong-Campbell Interest Inventory, which was further revised in 1981 (Barak \& Cohen, 2002). The test contains 325 activities, subjects, etc. Takers of this test are asked whether they like, dislike, or are indifferent to 325 items representing a wide variety of school subjects, occupations, activities, and types of people. They are also asked to choose their favorite among pairs of activities and indicate which of 14 selected characteristics apply to them. The Strong-Campbell test is scored according to 162 
separate occupational scales as well as 23 scales that group together various types of occupations.

Many researchers have developed interest inventory in different subjects, Obika (2004) developed interest inventory for economics students. The instrument is a 50 item questionnaires administered to a sample of 1000 students. Factor analysis yielded five factors namely: strategies, practical activities, concept application and motivation. Snow (2010) also developed twenty seven item mathematics interest inventory. The instrument was administered to a sample of 1,429 students in grade two through six. Results of confirmatory factor analysis a supported a four factor solution of emotion, value, knowledge and engagement

Presently, there is paucity of interest scale for measurement of student interest in geography. Therefore knowing the interest level of the students offering the subject will help the school counselor, the geography teacher and the school management to devise better strategies that will help students develop interest in the subject and possibly increase enrollment. The paucity of geography interest inventory can be attributed to teachers' poor knowledge in development and psychometrics validation of interest inventory. Therefore, this study focus on development and psychometrics validation of geography interest inventory for students using both exploratory and confirmatory factor analysis.

\section{Method}

The sample for the study consists of 494 students (194 male and 300 females) that were randomly selected from 34 secondary schools in Delta State, Nigeria. The instrument was developed based on literature review and interview obtained from the students on their interest in geography. The instrument has four subscales namely: value, emotion, engagement and knowledge with 27 items, item 5, 6, 7, 8,10 and 18 measuring value, item 4, 19, 20, 21, 22, and 23, measuring knowledge, item 1, 2, 3, 9,24,25,26 and 27 measuring emotion while item measuring $11,12,13,14,15,16$, and 17 measuring engagement. Item 1, 3, 5, 7, 8, 11, 12, 13, $14,15,16,17,22,23,25,26$ and 27 were positively worded while item 2, 4, 6, 9, 10, 18, 20, 21, 24 were negatively worded and were reversed scored. The instrument has five scoring format of Strongly Like $(\mathrm{SL}=5)$, Like $(\mathrm{L}=4)$, Neutral $(\mathrm{N}=3)$, Dislike $(\mathrm{D}=2)$ and Strongly Dislike $(\mathrm{SD}=1)$. The instrument was administered to the students with the help of three research assistants.

The collected data (sample) was randomly split into two halves. The first half (247) was used for Exploratory factor analysis (EFA) while the second sample (247) was used for confirmatory factor analysis. Both the EFA and CFA were conducted using Pysch and Lavaan Packages of R computing Language

\section{Results}

Exploratory factor analysis (EFA) 
Preliminary analysis was conducted to ascertain if the assumption of normality of data was violated, Prior to the EFA, mean, standard deviation, kurtosis, skewedness and was conducted on each item. Table 1 shows that most of items were skewed and such the assumption of normality was not met. Furthermore, Mardia test (skew $=13978.44, p=0.00$, kurtosis $=50.27, p=0.00$ ) of multivariate normality also show that assumption of normality was violated hence principal axis factoring was chosen as the extraction technique. Bartlett's sphericity test was used to investigate whether the intercorrelation matrix contains sufficient common variance to make the factor analysis viable. The significant $\chi 2$ value, $\chi 2$ (231) 456.23, p=0.001 and the high Kaiser-MeyerOlkin value, 0.84, support the use of EFA (Field, 2005). Following Hinkin (1998), since principal component analysis mixes common, specific and random error variances, a common factoring method such as principal axis was chosen as the extraction technique. Common factor analysis was more appropriate since the purpose was to identify underlying dimensions among the items, not data reduction (Bandalos \& Boehm-Kaufman, 2009). The oblique rotation method is more appropriate than orthogonal rotation method when variables under different factors are correlated (Bandalos \& Boehm-Kaufman, 2009). Since the items measure geography interest are interrelated, oblique rotation rather than orthogonal rotation was used. The data are not normally distributed, hence the extraction method of choice is principal axis factoring (PAF), because it does not assume normality of data (Brown, 2015). The recommended rotation method is oblimin (Fabrigar \& Wegener, 2012).

As shown in Figure 1 and 2, both parallel analysis scree and very simple structure were used as the rule of thumb, and resulted in four factors to be retained (Hinkin, 1998; Wang, 2003). The objective of using the EFA was to identify the items that most clearly represent the content domain of the underlying construct: items with an appropriate factor loading greater than 0.45 and/or a loading twice as strong on the appropriate factor as any other factor should be retained (Hinkin, 1998). Inappropriately loaded items are deleted, and the analysis is repeated until a clear factor structure matrix (i.e. simple factor structure) is obtained. The result is presented in table 2. 
30 | International Journal of Scientific and Management Research 4(6) 26-39

Table 1: Mean, standard deviation and skewedness of items and kurtosis of geography interest inventory

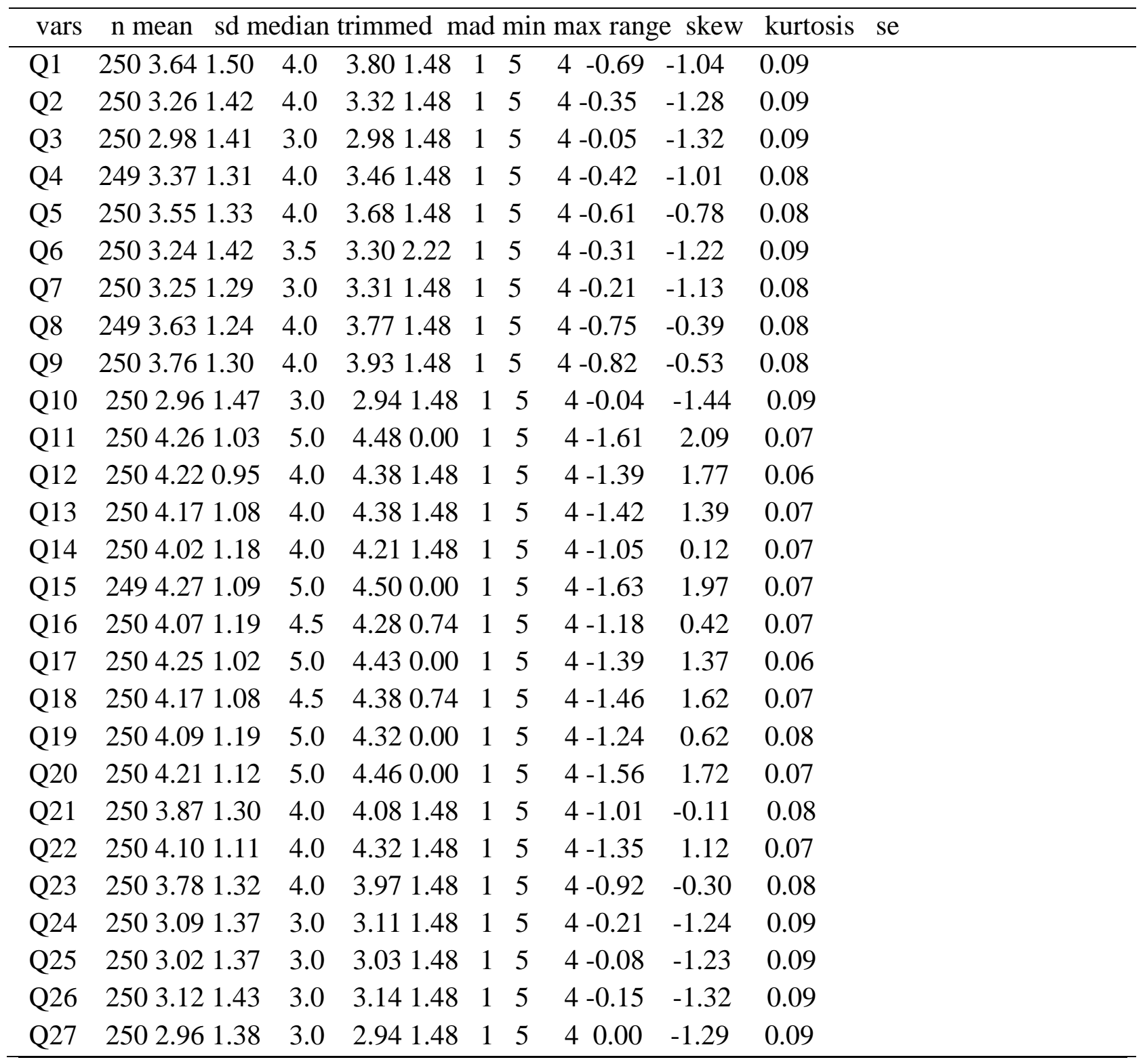




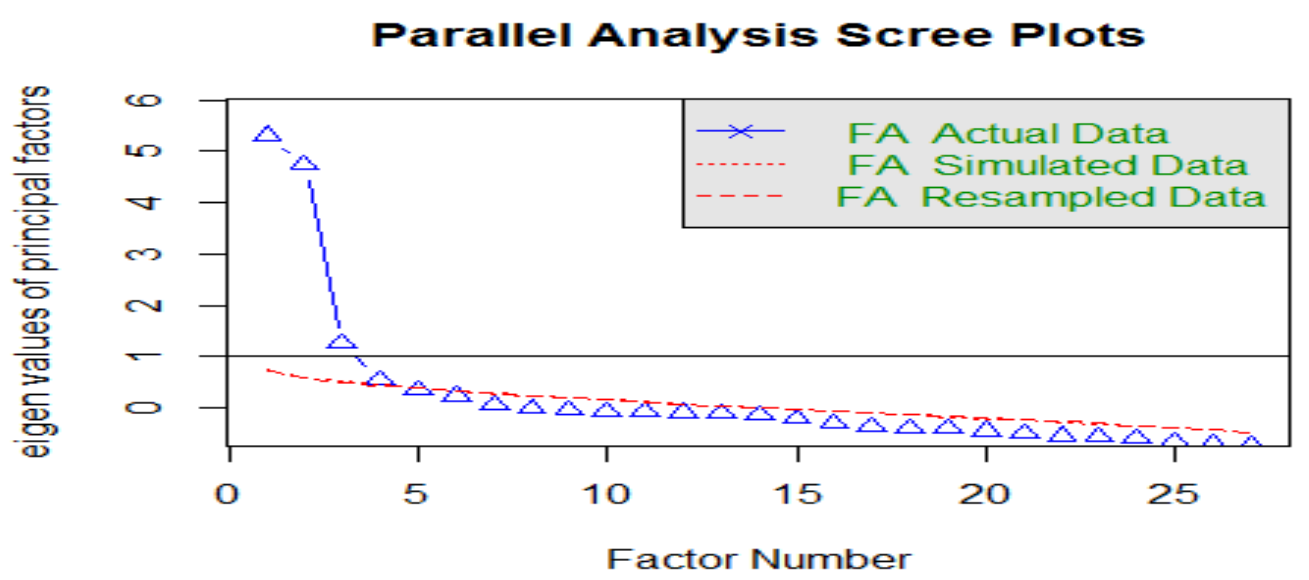

Fig1: Parallel analysis suggests that the number of factors $=4$

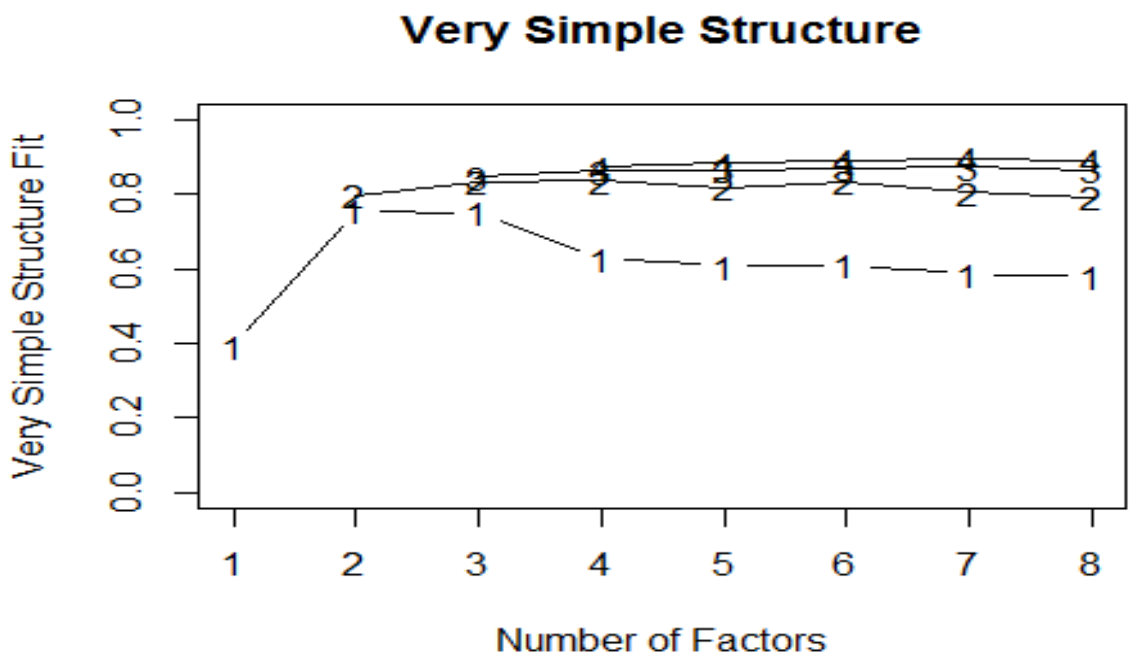

Fig 2: The result of very simple structure also indicate a four factor solution

An item communality (h2) is the $\%$ of item variance explained by the extracted factors. It may be considered as R2 in linear regression. The cut-off value of what is considered acceptable depends on the researcher; it depends on the amount of explained variance that is acceptable to him/her. A cut-off of 0.5 is practical (Hair et al., 2010), i.e. $50 \%$ of item variance is explained by all extracted factors. However, in practice, it depends on the minimum Factor loading accepted. For this study all items have communalities > 0.35 recommended (Wang, 2003).

In terms of factor correlations, correlations of $<0.85$ between factors are expectable in behavioural sciences. If the correlations are $>0.85$, the factors are not distinct from each other (factor overlap, or multicollinearity), thus they can be combined (Brown, 2015). From table 3 of the factors have correlation less than 0.85 . Therefore is no multicollinearity or factor overlap. 
32 | International Journal of Scientific and Management Research 4(6) 26-39

Table 2 items loading on each factor (EFA)

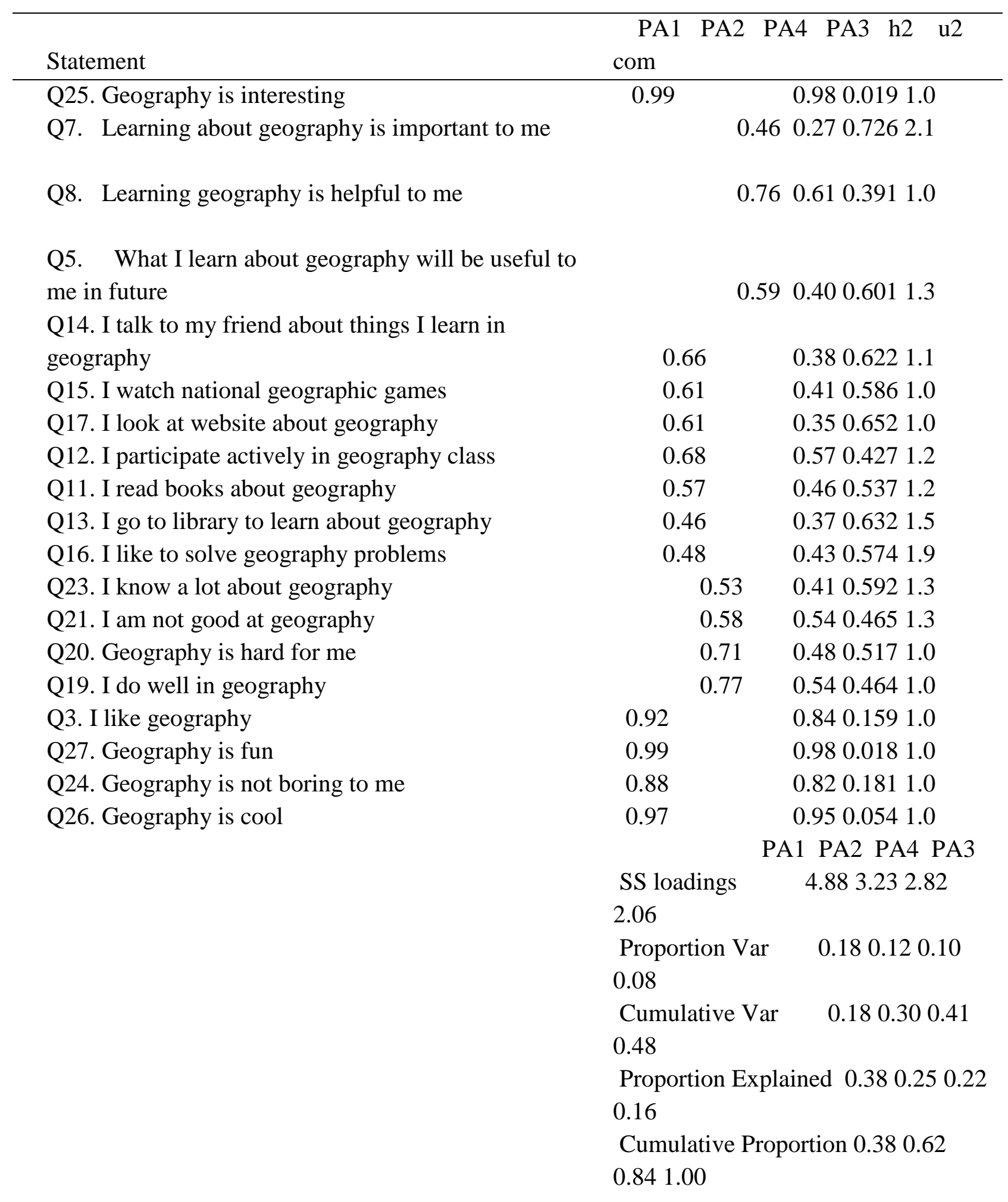

NB items that have loading below 0.45 were deleted from the table 
The Cronbach Alpha reliability of PA1 (Emotion) $=0.98$, PA2 (Engagement) $=0.82$, PA3 (Value) $=0.81$, and PA4 (Knowledge) $=0.62$. The overall Cronbach reliability of the instrument is 0.82 . The show that the instrument is reliability

Table 3 with factor correlations of geography interest inventory

\section{PA1 PA2 PA4 PA3}

PA1 1.00

PA2 -0.131 .00$

PA4 $0.02 \quad 0.521 .00$

PA3 0.310 .090 .141 .00

\section{Confirmatory factor analysis}

A confirmatory factor analysis was conducted to further validate the factor structure derived from EFA (Hinkin, 1998). The second half of the random sample (247) was used for the analysis. Preliminary analysis was conducted to ascertain if the assumption of normality of data was violated, mean and standard deviation were conducted on each item. Table 4 shows the descriptive statistics of each items. Furthermore, Mardia test (skew $=13963.44, p=0.00$, kurtosis $=51.27, \mathrm{p}=0.00$ ) of multivariate normality also show that assumption of normality was violated. The term of model fit, the threshold values of RMSEA $\leqslant 0.08$, SRMR $\leqslant 0.10, \mathrm{CFI} \geqslant 0.9$ and NNFI $\geqslant 0.9$ are recommended (Hair et al., 2010; Bentler and Bonett, 1980). The CFA results indicates model fit of the four-factor model derived from EFA is acceptable in CFA ( $\chi 2341.410$; df $=164 ; \mathrm{p}=0.000 ; \mathrm{CFI}=0.917$; RMESA $=0.066 ;$ SRMR $=0.063$ ). The average variance of emotion subscale $=0.91$, engagement subscale $=0.40$, value subscale $=0.45$ and knowledge $=0.40$. Therefore construct reliability of the instrument was also achieved using the CFA approach in validating the structure obtained through EFA. The standardized item loadings are all significant $(\mathrm{p}=0.001)$ in their respective factors as shown in table 5 . 
34 | International Journal of Scientific and Management Research 4(6) 26-39

Table 4: Descriptive Statistics for Observed Variables

\begin{tabular}{|c|c|c|c|c|c|}
\hline Variable & Mean & $\mathrm{SD}$ & Min & Max & $\%$ Missing \\
\hline Q10 & 2.96 & 1.47 & 1 & 5 & 0.0 \\
\hline Q11 & 4.26 & 1.03 & 1 & 5 & 0.0 \\
\hline Q12 & 4.22 & 0.95 & 1 & 5 & 0.0 \\
\hline Q13 & 4.17 & 1.08 & 1 & 5 & 0.0 \\
\hline Q14 & 4.02 & 1.18 & 1 & 5 & 0.0 \\
\hline Q15 & 4.27 & 1.09 & 1 & 5 & 0.4 \\
\hline Q16 & 4.07 & 1.19 & 1 & 5 & 0.0 \\
\hline Q17 & 4.25 & 1.02 & 1 & 5 & 0.0 \\
\hline Q18 & 4.17 & 1.08 & 1 & 5 & 0.0 \\
\hline Q19 & 4.09 & 1.19 & 1 & 5 & 0.0 \\
\hline Q20 & 4.21 & 1.12 & 1 & 5 & 0.0 \\
\hline Q21 & 3.87 & 1.30 & 1 & 5 & 0.0 \\
\hline Q22 & 4.10 & 1.11 & 1 & 5 & 0.0 \\
\hline Q23 & 3.78 & 1.32 & 1 & 5 & 0.0 \\
\hline Q24 & 3.09 & 1.37 & 1 & 5 & 0.0 \\
\hline Q25 & 3.02 & 1.37 & 1 & 5 & 0.0 \\
\hline Q26 & 3.12 & 1.43 & 1 & 5 & 0.0 \\
\hline Q27 & 2.96 & 1.38 & 1 & 5 & 0.0 \\
\hline Q5 & 3.55 & 1.33 & 1 & 5 & 0.0 \\
\hline Q6 & 3.24 & 1.42 & 1 & 5 & 0.0 \\
\hline Q7 & 3.25 & 1.29 & 1 & 5 & 0.0 \\
\hline Q8 & 3.63 & 1.24 & 1 & 5 & 0.4 \\
\hline Q9 & 3.76 & 1.30 & 1 & 5 & 0.0 \\
\hline
\end{tabular}


35 | International Journal of Scientific and Management Research 4(6) 26-39

Table 5.Factor Loadings from CFA

\begin{tabular}{|c|c|c|c|}
\hline $\begin{array}{l}\text { Latent } \\
\text { Factor }\end{array}$ & Indicator & p-value & Loading \\
\hline $\mathrm{F} 1$ & Q25 & 0.0 & 0.98 \\
\hline $\mathrm{F} 1$ & Q3 & 0.0 & 0.99 \\
\hline $\mathrm{F} 1$ & Q27 & 0.0 & 0.97 \\
\hline $\mathrm{F} 1$ & Q24 & 0.0 & 0.93 \\
\hline $\mathrm{F} 1$ & Q26 & 0.0 & 0.90 \\
\hline $\mathrm{F} 2$ & Q14 & 0.0 & 0.76 \\
\hline $\mathrm{F} 2$ & Q15 & 0.0 & 0.72 \\
\hline $\mathrm{F} 2$ & Q17 & 0.0 & 0.58 \\
\hline $\mathrm{F} 2$ & Q12 & 0.0 & 0.60 \\
\hline $\mathrm{F} 2$ & Q11 & 0.0 & 0.54 \\
\hline $\mathrm{F} 2$ & Q13 & 0.0 & 0.58 \\
\hline $\mathrm{F} 2$ & Q16 & 0.0 & 0.60 \\
\hline F3 & Q23 & 0.0 & 0.67 \\
\hline $\mathrm{F} 3$ & Q21 & 0.0 & 0.65 \\
\hline F3 & Q20 & 0.0 & 0.76 \\
\hline F3 & Q19 & 0.0 & 0.66 \\
\hline $\mathrm{F} 3$ & Q22 & 0.0 & 0.63 \\
\hline $\mathrm{F} 4$ & Q7 & 0.0 & 0.82 \\
\hline F4 & Q8 & 0.0 & 0.60 \\
\hline $\mathrm{F} 4$ & Q5 & 0.0 & 0.38 \\
\hline
\end{tabular}




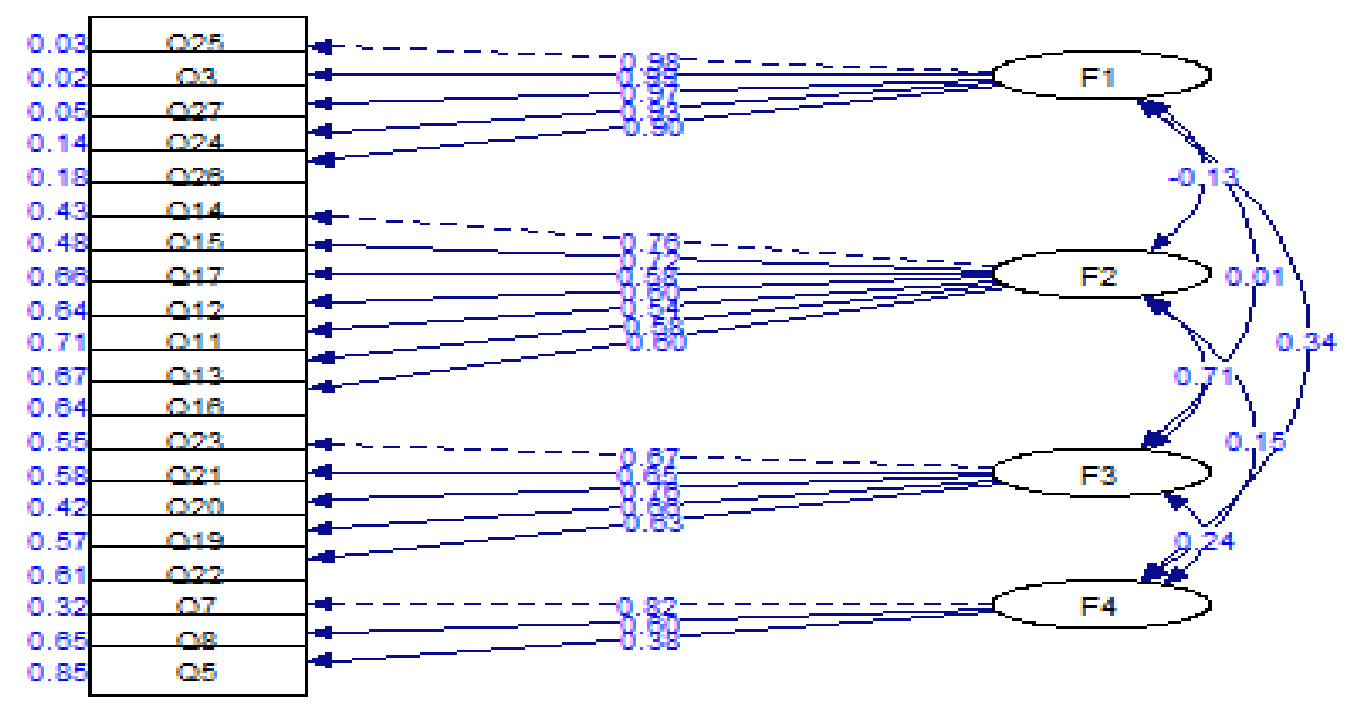

Fig 3: Path Diagram of Geography Interest Inventory

\section{Discussion and Conclusion}

The study is on development and psychometrics validation of geography interest inventory. The instrument has four subscales namely: value, emotion, engagement and knowledge with 27 items. The instrument was administered to a sample of 494 secondary school students with the help of two research assistants in Delta State, Nigeria. The sample was randomly split in two halves. The first sample 247 was used for Exploratory Factor Analysis (EFA). The results of the Exploratory Factor Analysis Results in Four Factor Solution that is emotion, value, Knowledge and engagement. The above study is in line with Hidi and Renniger (2006) have identified four dimensions of interest inventory namely emotion, value, knowledge and engagement. Furthermore, five items have loading above 0.45 cut -off under value dimension, seven items have loading above 0.45 cut -off under engagement dimension, three items have loading above 0.45 cut -off under value dimension, and four items have loading above 0.45 cut -off under value dimension, the above finding is line with Hinkin (1998) that recommended using the EFA to identify the items that most clearly represent the content domain of the underlying construct: items with an appropriate factor loading greater than 0.45 and/or a loading twice as strong on the appropriate factor than any other factor should be retained.

To validate the structure or factor, confirmatory factor analysis was conducted using a second sample of 247. The result of model fit in term of TLI, CFI, RMSEA and SRMR were above the 
recommended cut of 0.90 for CFI, TLI and less than 0.08 for RMSEA and SRMR respectively. The above study is line with Bentler and Bonett (1980) that recommended the threshold values of RMSEA $\leqslant 0.08, \mathrm{SRMR} \leqslant 0.10, \mathrm{CFI} \geqslant 0.9$ and $\mathrm{NNFI} \geqslant 0.9$ as good model fit for confirmatory factor analysis. Further the study also indicates that items loading in the respective dimension were significant. Therefore, the geography interest inventory is valid and reliable and can be used by the school counselors, the geography teachers and the school management to measure student interest level in geography so to help them develop interest in the subject and possibly increase enrollment.

\section{References}

1) Akintade BO (2011). Considering the determinants of selecting geography as a discipline: The case of Senior Secondary School Students in Ilorin, Nigeria. Ozean J. of Social Sci., (4)3: 131-138.

2) Arifin, W. N. (2015). The graphical assessment of multivariate normality using SPSS. Education in Medicine Journal, 7 (2), e71-e75.

3) Bandalos, D.L. and Boehm-Kaufman, M.R. (2009), "Four common misconceptions in exploratory factor analysis", in Lance, C.E. and Vandenberg, R.J. (Eds), Statistical and Methodological Myths and Urban Legends, Routledge, New York, NY, pp. 61-88.

4) Bangbade JO (2004). Effects of Subject Matter Knowledge in the Teaching and Learning of Biology and Physics: Teaching and Teacher education; pp. 109-102.

5) Barak A, \& Cohen L (2002). Empirical Examination of the Self-Direct Search. J. Career Assess., 10: 387-400.

6) Bartlett, M. S. (1951). The effect of standardization on a $\chi 2$ approximation in factor analysis. Biometrika, 38 (3/4), 337-344.

7) Brown, T. A. (2015). Confirmatory factor analysis for applied research. New York: The Guilford Press.

8) Courtney, M. G. R. (2013). Determining the number of factors to retain in EFA: Using the spss r-menu v2. 0 to make more judicious estimations. Practical Assessment, Research \& Evaluation, 18 (8), 1-14.

9) DeVellis, R. F. (2012). Scale development: Theory and applications (3rd ed). California: Sage publications.

10) EGUNJOBI, A. O. (2014). Effect of tutorial mode of computer instruction on student academic performance in secondary school pratical geography in Nigeria. AFRRN STECH, 3(1), 150-166.

11) Elochukwu CC (2001). Teachers Attributes in Secondary Schools in Nigeria as Hindrance to Educational Development. Proceedings of the National Conference on Standards in Education, which held at the University of Benin, Benin city: University of Benin Press. 
12) Estawu, S.S. Sababa, L.K. \&Filgona, J. (2016). Effects of field trips strategy on senior secondary school students academic achievement in geography in Numan Educational Zone of Adamawa, Nigeria. European Journal of Educational Studies, 2(12), 138-154.

13) Fabrigar, L., \& Wegener, D. (2012). Exploratory factor analysis. New York: Oxford University Press.

14) Fornell, C. and Larcker, D.F. (1981), Evaluating structural equation models with unobservable variables and measurement error", Journal of Marketing Research, Vol. 18 No. 1, pp. 39-50.

15) Gorsuch, R. L. (2014). Exploratory factor analysis. New York: Routledge.

16) Guilford, J.P. (1959). Personality. U.S.A, McGraw Hill Book Company.

17) Hair, J.F. Jr, Black, W.C., Babin, B.J. and Anderson, R.E. (2010), Multivariate Data Analysis: A Global Perspective, 7th ed., Prentice Hall, Upper Saddle River, NJ.

18) Hinkin, T.R. (1998), A brief tutorial on the development of measures for use in survey questionnaires, Organizational Research Methods, Vol. 1 No. 1, pp. 104-121.

19) Obika, G.A.(2004). Development and preliminary validation of economics interest scale for secondary schools. University of Nigeria Nsukka Thesis.

20) Okunrotifa PO (2008). Geography in Nigerian High School. New Zealand J. of Geo. 55 (1): 16-19. Olanipekun AO (1988). Economic and Social Implications of the New Geography Curriculum: in F. C. Okafor, A. R. O. Jibunoh, M. A. Abegunde, O. D. Awaritefe and Akinbode (eds) The New Geography: A Handbook for Practising Teachers.Warri: Nigerian Geography Teachers Association (SWZ): 69-92.

21) Rena U (2000). Who will Teach: A case Study of Teacher Education Reform. Caddo California Gap press: p. 381

22) Rilwani, M.C., Akahomen, D.O \& Gbakeji, J.O. (2014). Secondary school student's attrition in geography in Essan West G. g. A of Edo state._Sky Journal of Educational Research Vol. 2(4), 028 - 036,

23) Snow, G. M. (2011). Development of mathematics interest inventory to identify gifted children from underrepresented and diverse population.

24) Tabachnick, B. G., \& Fidell, L. S. (2012). Using multivariate statistics. Boston, MA: Allyn \& Bacon/Pearson Education.

25) WAEC (2015). West African Examinations Council, Chief Examiners 'Report May/June SSSCE pp. 14-16.

26) WAEC (2016). West African Examinations Council, Chief Examiners 'Report May/June SSSCE pp. 14-16.

27) WAEC (2017). West African Examinations Council, Chief Examiners 'Report May/June SSSCE pp. 14-16.

28) WAEC (2018). West African Examinations Council, Chief Examiners 'Report May/June SSSCE pp. 14-16.

29) WAEC (2019). West African Examinations Council, Chief Examiners`Report May/June SSSCE pp. 14-16. 


\section{Geography Interest inventory}

The instrument has five scoring format of Strongly Like ( $\mathrm{SL}=5)$, Like $(\mathrm{L}=4)$, Neutral $(\mathrm{N}=3)$, Dislike $(\mathrm{D}=2)$ and Strongly Dislike $(\mathrm{SD}=1)$.

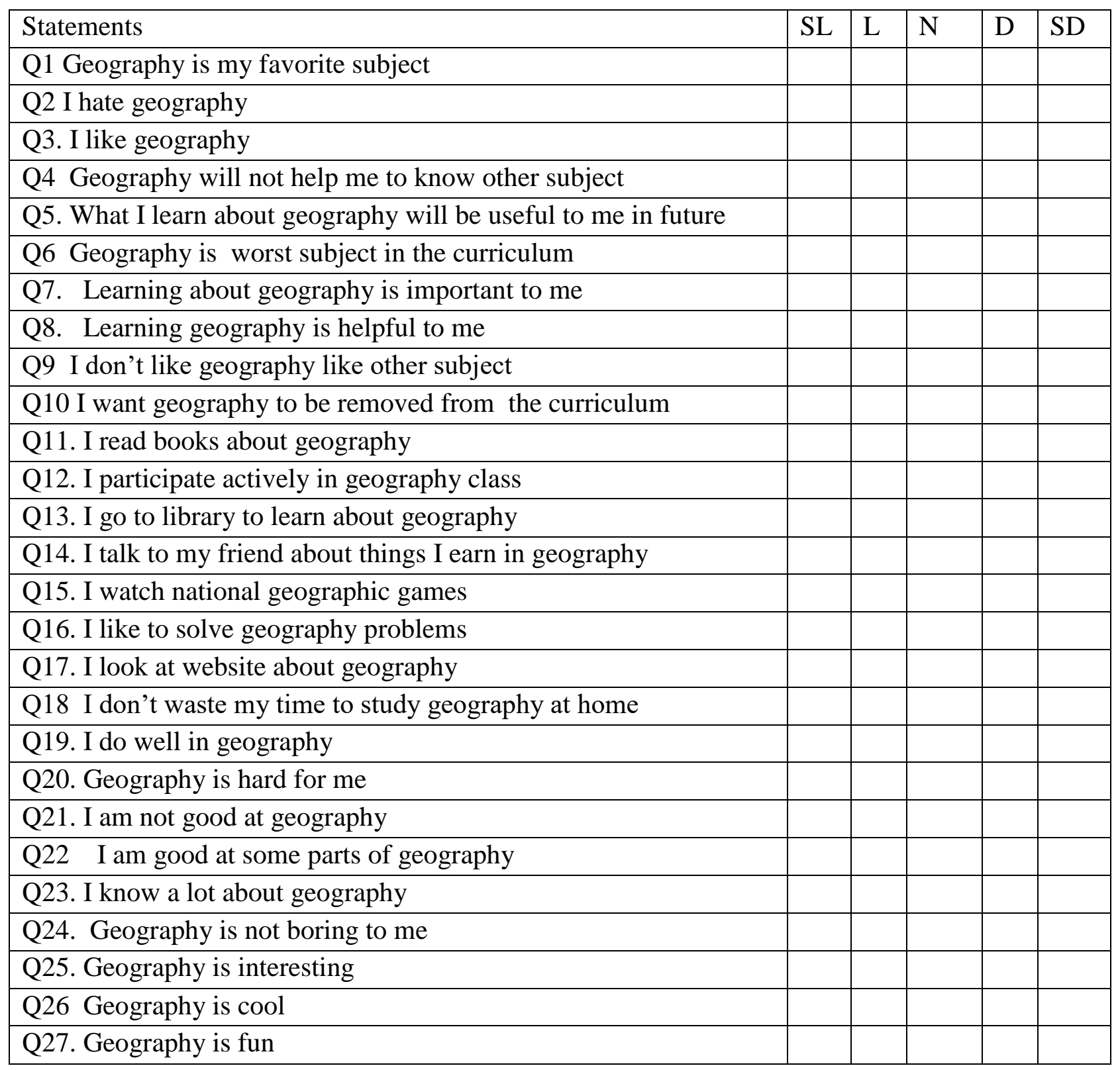

